\title{
Adsorption Batch Studies on the Removal of Pb(II) Using Maize Tassel Based Activated Carbon
}

\author{
Mambo Moyo, Linda Chikazaza, Benias Chomunorwa Nyamunda, and Upenyu Guyo \\ Department of Chemical Technology, Midlands State University, Private Bag 9055, Senga, Gweru, Zimbabwe \\ Correspondence should be addressed to Mambo Moyo; moyom@msu.ac.zw
}

Received 22 May 2013; Revised 31 July 2013; Accepted 17 August 2013

Academic Editor: Kaustubha Mohanty

Copyright (C) 2013 Mambo Moyo et al. This is an open access article distributed under the Creative Commons Attribution License, which permits unrestricted use, distribution, and reproduction in any medium, provided the original work is properly cited.

The demand for clean water is on the increase as rapid industrialization is still contributing to pollution. Nowadays, as water is the basic need for mankind, efforts have gathered momentum to decontaminate it in order to address the acute shortage of clean and pure water. Maize tassel was used as the precursor for making activated carbon for the adsorption of $\mathrm{Pb}$ (II) ions. The product obtained was characterized and utilized for the removal of $\mathrm{Pb}(\mathrm{II})$ from aqueous solutions over a wide range of initial metal ion concentration $(10-50 \mathrm{mg} / \mathrm{L})$, contact time (5-300 $\mathrm{min})$, adsorbent dose (0.1-2.5 g), and $\mathrm{pH}(2-12)$. The optimum set of conditions for biosorption of $\mathrm{Pb}(\mathrm{II})$ ion were found to be initial concentration $10 \mathrm{mg} / \mathrm{L}$, dosage $1.2 \mathrm{~g}$, and $\mathrm{pH}$ 5.4. The adsorption data conformed to both the Langmuir and the Freundlich isotherms but fitted best into the Langmuir model. The $R^{2}$ for Langmuir equation was 0.9997 and that for Freundlich was 0.9515 . The Langmuir monolayer adsorption capacity of the activated carbon was calculated to be $37.31 \mathrm{mg} / \mathrm{g}$. The results indicate that activated carbon might be used to effectively adsorb $\mathrm{Pb}$ (II) ions from wastewater treatment plants.

\section{Introduction}

Nowadays water pollution by heavy metals is fast growing due to natural processes and increasing human activities which include mining, agriculture, and manufacturing industries. These heavy metals are nondegradable and cannot be detoxified biologically [1]. Lead $(\mathrm{Pb})$ is among those contaminants that must be removed from water, due to its high toxicity and tendency to accumulate in tissues of living organisms [2-4]. $\mathrm{Pb}$ can occur in different forms such as organic and inorganic forms. $\mathrm{Pb}$ is the most significant toxin of the trace metal ions, and human exposure to the inorganic forms is through ingestion of food, water, and inhalation. The aforementioned form affects mainly the peripheral nervous system and haematopoietic, renal, gastrointestinal, cardiovascular, and reproductive systems. Organic $\mathrm{Pb}$ mainly affects the central nervous system. According to World Health Organization [5], the permissible level for $\mathrm{Pb}$ in drinking water is $0.05 \mathrm{mg} / \mathrm{L}$. Therefore, it is necessary to remove $\mathrm{Pb}$ from wastewaters before discharging into the natural water bodies.

One of the ways to address this problem of water shortage is to treat the polluted water through removal of the contaminants. To date, the removal of metals from water has been previously achieved by various methods such as ion exchange, precipitation, oxidation, reduction, and membrane filtration $[6,7]$. Compared with these techniques, adsorption technology, using some cheap, easily available agricultural plants, algal biomass, and cyanobacteria, has been reported [8-10]. However, the use of raw sorbents in adsorption has its problems since most plants contain a green pigment known as chlorophyll (sparingly soluble in water), and some organic matter may be leached out, consequently affecting the taste and colour of the treated waters [11, 12]. In spite of the versatility of commercial activated carbon as an adsorbent in wastewater treatment due to its high surface area, microporous characteristics, and high adsorption capacity, it remains costly in developing countries [13-15]. Hence, the derivation of activated carbon from some natural plant based materials might reduce the highlighted problems. In the recent past, activated carbon sorbents derived from locally available materials such as Ceiba pentandra hulls [16], Euphorbia rigida [17], hazelnut husks [18], wheat bran [19], apple waste [20], coconut shell [21], and Terminalia arjuna nuts [22] have received increasing attention for the removal and recovery of pollutants in aqueous media. 
Maize is a versatile cereal crop that is grown widely throughout the world in a range of agroecological environments. Maize is a fast growing, vigorous and tall (2$3 \mathrm{~m})$ cereal crop having broad $(5-10 \mathrm{~cm})$, and long (50$100 \mathrm{~cm}$ ) leaves. Maize tassel, an inexhaustible, nonedible, and renewable polymeric material resource, is the male part of the maize plant which is discarded as waste. As a way to address issues related to sustainability, the lignocellulosic material possesses several desirable characteristics to use an adsorbent (a low cost material, mesoporous) and hence can be used as a good precursor of activated carbon [23].

The present study aims at assessing the adsorption potential of activated carbon prepared from maize tassel for the removal of $\mathrm{Pb}(\mathrm{II})$ ions from aqueous solutions. The interactive effects of process parameters such as adsorbent dosage, agitation time, solution $\mathrm{pH}$, and initial concentration on the adsorption capacity of activated carbon towards $\mathrm{Pb}$ (II) are demonstrated.

\section{Materials and Methods}

2.1. Preparation of Biomass. The maize tassel was collected from Morris farm in Northlea, Gweru, Zimbabwe. This material is a zero-value agricultural waste product. Maize tassel was plucked off the woody parts of the maize plant, thoroughly washed with water, and sun dried for 5 days. The dried biomass was milled and then fractionated using $100-$ $300 \mu \mathrm{m}$ analytical sieves and washed twice with $0.01 \mathrm{M} \mathrm{HCl}$ in order to remove any metals that might be on the biomass.

2.2. Preparation of Activated Carbon. The activate carbon was prepared according to the reported procedures [24, 25]. Briefly, the fractionated maize tassel powder $(200 \mathrm{~g})$ was weighed in a clean dry beaker of capacity $1 \mathrm{~L}$ containing $\left(200 \mathrm{~mL}, 97 \% \mathrm{H}_{2} \mathrm{SO}_{4}\right.$ for $24 \mathrm{~h}$ ) followed by refluxing in a fume hood for $4 \mathrm{~h}$. After cooling, the reaction mixture was filtered, and the filtrate was washed repeatedly with ultrapure water and soaked in $1 \% \mathrm{NaHCO}_{3}$ solution to neutralise any remaining acid. The sample was then washed with distilled water until the $\mathrm{pH}$ of the activated carbon was between 6 and 7 , dried overnight in an oven at $120^{\circ} \mathrm{C}$, and kept in a glass bottle until use.

2.3. Characterization of Prepared Activated Carbon. The bulk density was determined by transferring activated carbon to a $10 \mathrm{~mL}$ measuring cylinder of about $1.0 \mathrm{~cm}$ diameter. Sufficient quantity of carbon powder was added to occupy a volume of $10 \mathrm{~mL}$ under the condition, and it was subsequently weighed. The bulk density was expressed as grams per litre (the weight of the activated carbon filling a graduated cylinder on gentle tapping, divided by the volume of the cylinder $10 \mathrm{~mL}$ ). The simple specific surface area, loss of mass on ignition, $\mathrm{pH}$, and moisture content were also determined [26, 27]. The FTIR spectra of activatedcarbon were obtained with $\mathrm{KBr}$ using Shimadzu model $R$-prestige Fourier Transform Infrared Spectrometer. FTIR spectra were recorded in the region of $4000-400 \mathrm{~cm}^{-1}$. X-ray powder diffraction (XRD) analysis of the activated carbon was carried out on a Bruker D8 Advance X-ray diffractometer using nickel filtered $\mathrm{Cu} \mathrm{K}_{\alpha}$ radiation $(40 \mathrm{kV}, 40 \mathrm{~mA})$. The $\mathrm{pH}$ of solutions was measured with a proLab 200 (SCHOTT instruments).

2.4. Adsorbate. A stock solution of $1000 \mathrm{mg} / \mathrm{L} \mathrm{Pb}$ (II) was prepared by dissolving $\mathrm{Pb}\left(\mathrm{NO}_{3}\right)_{2}$ (Merck, South Africa)

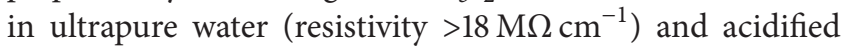
with $5 \mathrm{~mL}$ of concentrated $\mathrm{HNO}_{3}$ to prevent hydrolysis. The progressive dilution procedure of the stock solution was employed in the preparation of working solutions. The $\mathrm{pH}$ of the working solutions was adjusted to the required values with $0.1 \mathrm{M} \mathrm{NaOH}$ or $0.1 \mathrm{M} \mathrm{HCl}$. All the chemicals used were of analytical reagent grade.

2.5. Batch Adsorption Studies. A weighed amount of activated carbon was introduced into stoppered reagent bottles containing various concentrations with $100 \mathrm{~mL}$ aqueous solutions of $\mathrm{Pb}(\mathrm{II})$ ions. The suspensions were shaken at room temperature $\left(25 \pm 1^{\circ} \mathrm{C}\right)$ using a mechanical shaker for a prescribed time at $160 \mathrm{rpm}$. Scheme 1 shows the schematic representation of the process involved in the derivation of activated carbon from raw maize tassel up to adsorption. The solutions were filtered through Whatman 42 filter paper, and the residual concentration of metal ion was determined by AAS method at $217 \mathrm{~nm}$. The effects of concentration (10$50 \mathrm{mg} / \mathrm{L}$ ), contact time (5-300 min), solution $\mathrm{pH}(2-12)$, and adsorption dose (0.1-2.5 g) were studied. Blank solutions were treated similarly (without adsorbent), and the recorded concentration at the end of each operation was taken as the initial one.

The amount of metal adsorbed by activated carbon was calculated from the difference between metal quantity added to the biomass and metal content of the supernatant using

$$
q_{e}=\frac{\left(C_{i}-C_{e}\right) V}{M},
$$

where $q_{e}$ is the metal uptake (mg metal adsorbed per $\mathrm{g}$ adsorbent), $C_{i}$ and $C_{e}$ are the initial and equilibrium metal concentration in solution $(\mathrm{mg} / \mathrm{L}), V$ is the volume of the solution $(\mathrm{mL})$, and $M$ is the weight of activated carbon $(\mathrm{g})$. The percentage of removed $\mathrm{Pb}$ (II) ions $(R \%)$ in solution was calculated using

$$
R \%=\frac{\left(C_{i}-C_{e}\right) 100}{C_{i}} .
$$

2.6. Desorption Studies. For the desorption studies, contact was made between $1.2 \mathrm{~g}$ of activated carbon and a $100 \mathrm{~mL}$ $\mathrm{Pb}$ (II) solution. After $\mathrm{Pb}$ (II) ion sorption, the activated carbon was filtered, washed three times with ultrapure water to remove residual $\mathrm{Pb}$ (II) ions on the surface, and kept in contact with the $100 \mathrm{~mL} \mathrm{HCl}$ solution (0.05-0.3 M desorbent). The mixtures were shaken in a rotary shaker. The filtrates were analyzed to determine the concentration of $\mathrm{Pb}$ (II) ions after desorption using AAS.

\section{Results and Discussion}

3.1. Physicochemical Characteristics of Activated Carbon. The physicochemical characteristics like $\mathrm{pH}$, moisture content, 


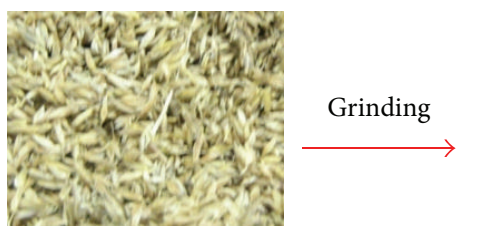

Raw maize tassel

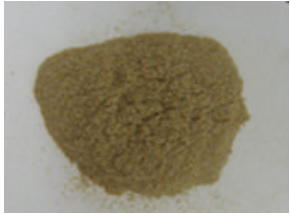

Maize tassel powder

Chemical activation

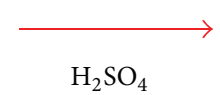

$\mathrm{H}_{2} \mathrm{SO}_{4}$

Activated carbon
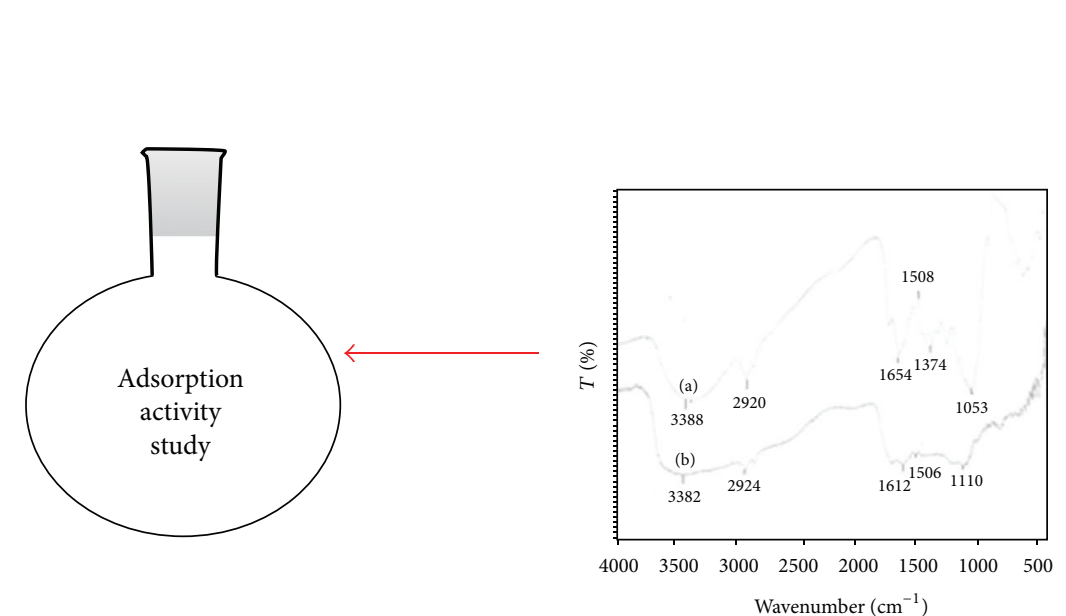

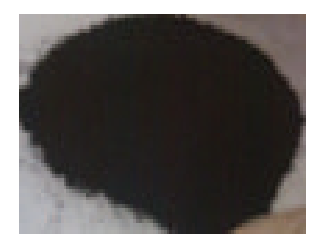

Characterization

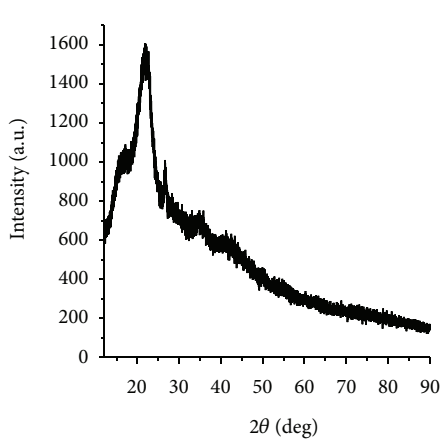

Scheme 1: Schematic representation of the process involved in the derivation of activated carbon from raw maize tassel up to adsorption.

TABLE 1: Characteristics of the activated carbon derived from maize tassel.

\begin{tabular}{lc}
\hline Parameter & Value \\
\hline $\mathrm{pH}$ & 6.9 \\
Moisture $(\%)$ & 0.3 \\
Bulk density $\left(\mathrm{gmL}^{-1}\right)$ & 0.52 \\
Surface area $\left(\mathrm{m}^{2} / \mathrm{g}\right)$ & 250 \\
Particle size range $(\mu \mathrm{m})$ & $100-300$ \\
\% Loss of mass on ignition & 0.7 \\
\hline
\end{tabular}

bulk density, surface area, and loss of mass on ignition are shown in Table 1. The bulk density affects the rate of adsorption of metals ions onto activated carbon. In the present study, the bulk density was less than 1.2 indicating that the activated carbon materials are in fine nature and hence enhanced the adsorption of $\mathrm{Pb}(\mathrm{II})$ ions from aqueous solution. The moisture content $(0.3 \%)$ was determined, even though it does not affect the adsorption power, dilutes the adsorbents, and therefore necessitates the use of additional weight of adsorbents to provide the required weight. The surface area of the prepared activated carbon in the present research study was $250 \mathrm{~m}^{2} / \mathrm{g}$ and is higher than a low cost agro-based adsorbent such as palm pith carbon $\left(188 \mathrm{~m}^{2} / \mathrm{g}\right)$ [28] but lower than peanut hull carbon $\left(354 \mathrm{~m}^{2} / \mathrm{g}\right)$ [29].

The X-ray diffraction pattern of the activated carbon is shown in Figure 1. The XRD spectrum of activated carbon is a typical diffraction pattern of an amorphous material which gives a continuous function and had two partially, not well

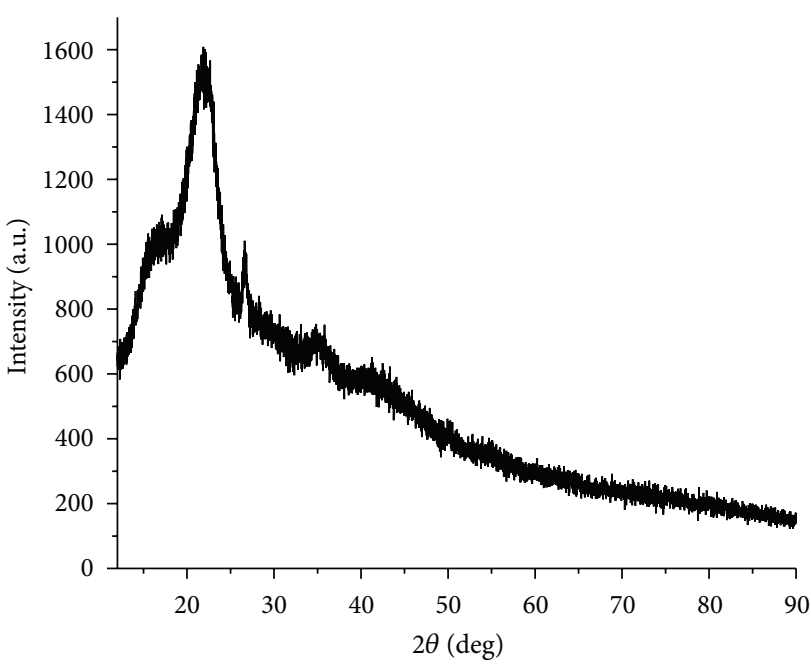

FIGURE 1: X-ray diffraction of activated carbon derived from maize tassel.

defined resolved peaks at about $2 \theta=$ angle of 22.6 and 26.4 degrees, respectively.

The FT-IR spectrum was obtained for treated activated carbon before (a) and after $\mathrm{Pb}$ (II) ion biosorption process (b) (Figure 2). The results showed us that the activated carbon has different functional groups such as amide, hydroxyl, and carboxyl. Some of these functional groups changed after biosorption process. The comparisons of the FT-IR spectra of 


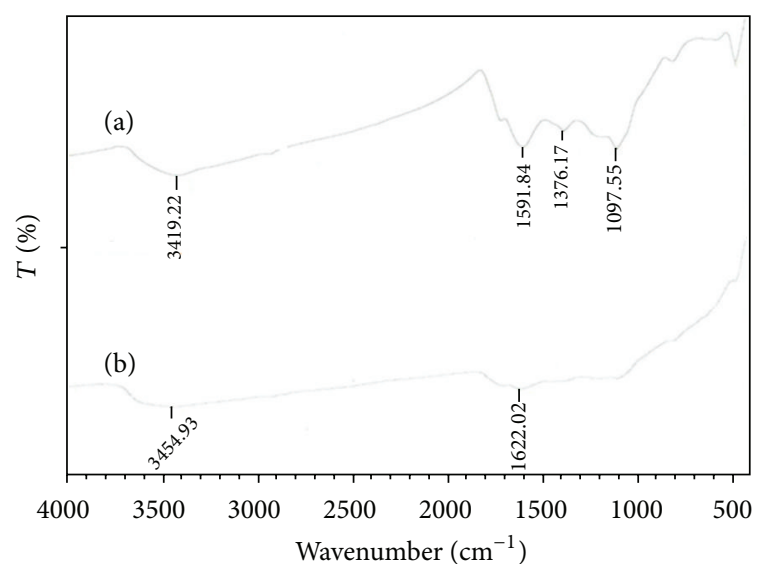

FIGURE 2: FT-IR spectra of treated activated carbon (a) and $\mathrm{Pb}$ (II) loaded activated carbon (b).

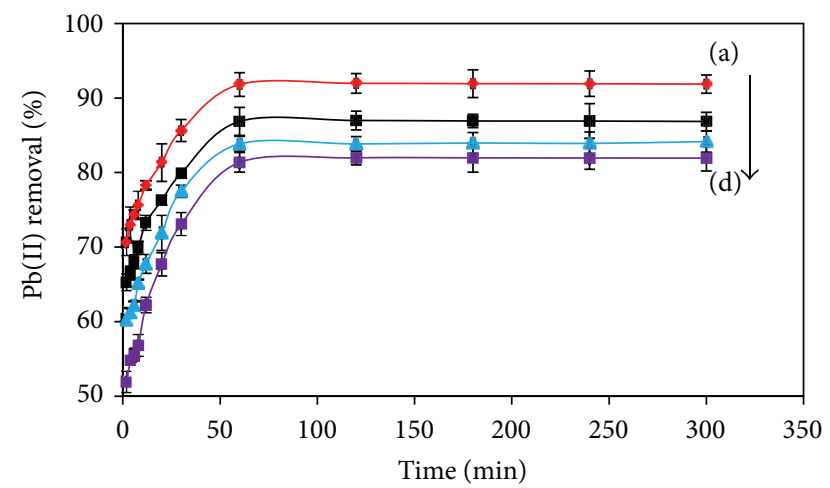

FIGURE 3: Effects of agitation time on lead ions removal (concentrations: a to d: $10 \mathrm{mg} / \mathrm{L}$ to $50 \mathrm{mg} / \mathrm{L}$; adsorbent dosage: $1.2 \mathrm{~g}$; $\mathrm{pH}$ : 5.4 ; error bar $= \pm$ S.D.; and $n=3$ ).

activated carbon and after $\mathrm{Pb}(\mathrm{II})$ biosorption give the following bands and peaks. The bands at 3419.22 and $3454.93 \mathrm{~cm}^{-1}$ are the $\mathrm{OH}$ stretching of polymeric compounds. The bands located at 1376.17 and $1591.84 \mathrm{~cm}^{-1}$ are possibly due to the functional groups like $\mathrm{C}=\mathrm{O}$ in carboxylic groups and carboxylate moieties. The additional small peaks at $1090.55 \mathrm{~cm}^{-1}$ indicate the $\mathrm{S}=\mathrm{O}$. The band at $1622.02 \mathrm{~cm}^{-1}$ corresponds to carbonyl stretching vibration of amide considered to be due to the combined effect of double-bond stretching vibration and $-\mathrm{NH}$ deformation band for $\mathrm{Pb}(\mathrm{II})$ loaded activated carbon. The $\mathrm{C}=\mathrm{O}$ and $\mathrm{S}=\mathrm{O}$ functional groups have been reported to show very high coordination with trace metals; hence it disappeared in the $\mathrm{Pb}$ (II) loaded [14]. For this reason, the presence of these functional groups may be responsible for good adsorptive behavior of the activated carbon towards the $\mathrm{Pb}(\mathrm{II})$ ions.

3.2. Effect of Agitation Time and Initial Concentration on Adsorption. The effect of agitation time is one of the important factors when designing batch sorption systems for economical wastewater treatment plant application. As shown in Figure 3 , the relationship between agitation time and $\mathrm{Pb}(\mathrm{II})$

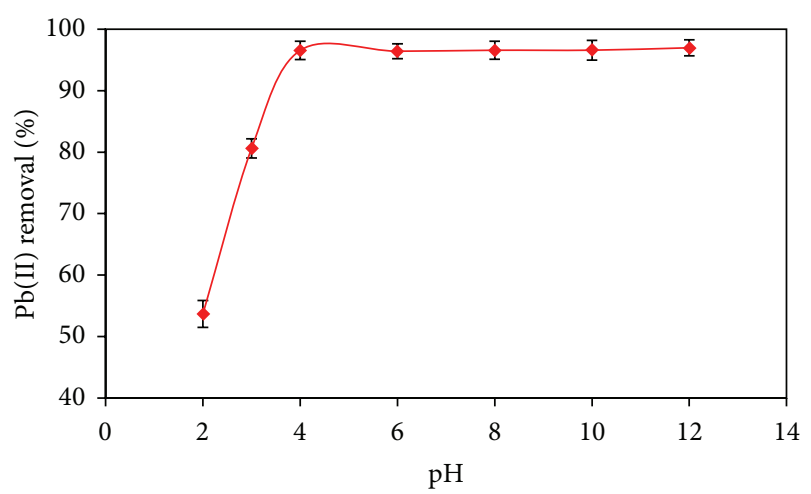

FIgURE 4: Effect of $\mathrm{pH}$ on lead adsorption by activated maize tassel (contact time: $60 \mathrm{~min}$; dosage $1.2 \mathrm{~g}$; initial concentration $10 \mathrm{mg} / \mathrm{L}$; error bar $= \pm$ S.D.; and $n=3$ ).

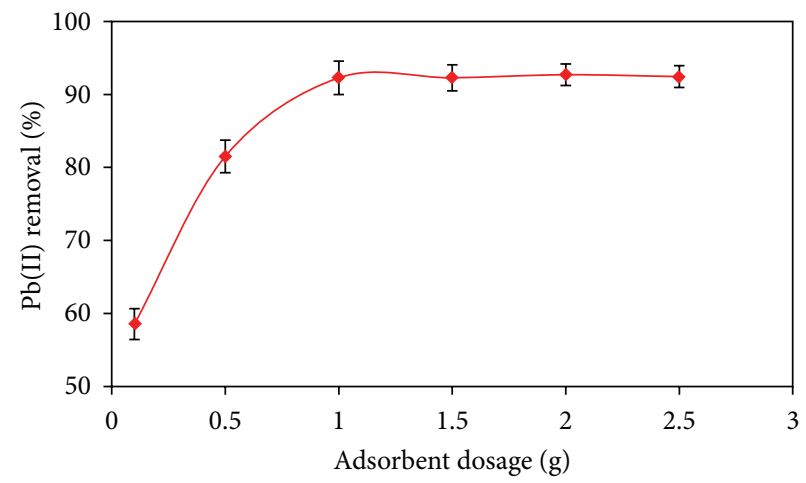

FIGURE 5: Effect of adsorbent dosage on lead adsorption by activated maize tassel (contact time: $60 \mathrm{~min}$; dosage $1.2 \mathrm{~g}$; initial concentration $10 \mathrm{mg} / \mathrm{L}$; error bar $= \pm$ S.D.; and $n=3$ ).

ion sorption onto activated carbon at different initial $\mathrm{Pb}(\mathrm{II})$ ion concentrations is displayed.

It was observed that $52,60,65$, and $70 \%$ of $\mathrm{Pb}$ (II) ions were removed in the first two minutes for the different concentrations $(10,20,30$, and $50 \mathrm{mg} / \mathrm{L}$, resp.), and the process was rapid up to $60 \mathrm{~min}$ attaining $91.8 \%$ removal for $10 \mathrm{mg} / \mathrm{L}$. Beyond $60 \mathrm{~min}$, the percentage of biosorption is almost constant indicating the attainment of equilibrium conditions. The presence of adequate external surface area on the activated carbon may have boosted the rate of adsorption in the initial stages which was followed by a slower internal diffusion process, which may be the rate determining step [30]. Therefore, all other experiments were conducted at an agitation time of $60 \mathrm{~min}$.

The effect of initial concentration on the percentage removal is also shown in Figure 3. The removal of $\mathrm{Pb}$ (II) ions by activated carbon was found to decrease with increase in initial $\mathrm{Pb}(\mathrm{II})$ concentration. The observed behavior can be attributed to the increase in the amount of $\mathrm{Pb}$ (II) ions to the unchanging number of available active sites on the activated carbon. Hence, more metal ions were left in solution. Thus, it 
can be said that removal of $\mathrm{Pb}$ (II) ion is highly concentration dependent.

3.3. Effect of $\mathrm{pH}$ on Adsorption. The effect of initial $\mathrm{pH}$ of a solution is a major factor used to determine the adsorption property of an adsorbent from waste water. The possible reasons are its effects on the chemistry of the ions and the activity of functional groups (carboxylate, phosphate, and amino groups) on the cell walls $[19,31]$. As revealed in Figure 4, there is a change in the quantity of adsorbed $\mathrm{Pb}$ (II) ions on the solid phase of activated carbon by increasing $\mathrm{pH}$ of the medium up to a maximum value of $\mathrm{pH}$ 5.4. At low $\mathrm{pH}$ values, the adsorbent is positively charged since the $\mathrm{pH}$ is lower than the isoelectric point or point of zero charge (PZC) [13]. Hence the removal yield of $\mathrm{Pb}(\mathrm{II})$ ions is very low due to the electrostatic repulsion forces between positively charged $\mathrm{H}_{3} \mathrm{O}^{+}$and $\mathrm{Pb}^{2+}$ ions. Thereafter the adsorption percentage decreased in alkaline medium perhaps due to the formation of $\mathrm{Pb}(\mathrm{OH})_{2}$ and soluble hydroxyl complexes such as $\mathrm{PbOH}^{+}$, aqueous $\mathrm{Pb}(\mathrm{OH})_{2}$, and $\mathrm{Pb}(\mathrm{OH})^{3-}$, and the activated carbon was deteriorated with the accumulation of $\mathrm{Pb}$ (II) ions making true adsorption studies impossible [32-34]. Similar trends were reported for adsorption of $\mathrm{Pb}(\mathrm{II})$ ions on activated carbon prepared from coconut shell [35], Euphorbia rigida [17], sawdust [36], and mature pods of $M$. Oleifera containing seeds [37]. The results obtained in this study indicated that the activated carbon is more effective in removing $\mathrm{Pb}(\mathrm{II})$ ions from an aqueous system with $96.6 \%$ removal as compared to raw maize tassel (75\%) [38], tobacco stems (94.37\%) [30], and physically prepared AC (78\%) [39]. Therefore, $\mathrm{pH} 5.4$ was selected to be the optimum $\mathrm{pH}$ for all further studies.

3.4. Effects of Dosage on Adsorption. The effect of biomass dosage on the biosorption of $\mathrm{Pb}(\mathrm{II})$ ions was investigated (Figure 5). As shown in Figure 5, the percentage removal increases sharply from $58.5 \%$ to $92.2 \%$ with increasing dosage from 0.1 to $1.2 \mathrm{~g}$, respectively. Beyond $1.2 \mathrm{~g}$, the percentage was not increased significantly and reached the maximum of $92.3 \%$ at dosage of $1.2 \mathrm{~g}$. This phenomenon can be due to the greater availability of active sites or surface area making easier penetration of the $\mathrm{Pb}(\mathrm{II})$ ions to the adsorption sites of activated carbon, and increasing beyond dosage of $1.2 \mathrm{~g}$ had no much effect after equilibrium is reached. These results are in agreement with other work reported in the literature $[2,34]$.

3.5. Adsorption Isotherms. Adsorption isotherms are very useful for analyzing the nature of adsorbate-adsorbent interaction. So, in order to optimize the design of a successful adsorption unit to remove trace metal ions from industrial effluents, it is significant to establish the best correlation for the equilibrium isotherms. In this study, the equilibrium data for the adsorbed $\mathrm{Pb}(\mathrm{II})$ ions onto activated carbon was expressed using two of the most popular isotherms, namely, Langmuir and Freundlich isotherms.

The Freundlich isotherm [40] is given by

$$
q_{e}=K_{F} C_{e}^{1 / n} .
$$

TABLE 2: Langmuir and Freundlich constants for $\mathrm{Pb}(\mathrm{II})$ adsorption using activated carbon.

\begin{tabular}{lcc}
\hline Adsorption isotherm & Parameter & Value \\
\hline \multirow{3}{*}{ Langmuir } & $q_{\max }(\mathrm{mg} / \mathrm{g})$ & 37.31 \\
& $b(\mathrm{~L} / \mathrm{mg})$ & 0.062 \\
& $R^{2}$ & 0.9997 \\
Freundlich & $K_{F}$ & 0.077 \\
& $n$ & 0.482 \\
& $R^{2}$ & 0.9515 \\
\hline
\end{tabular}

The parameters can be linearized by taking logarithms to determine the parameters $K_{F}$ and $n$ :

$$
\ln q_{e}=\ln K_{F}+\frac{1}{n} \ln C_{e} .
$$

A plot of $\ln q_{e}$ versus $\ln C_{e}$ gives a straight line, and $K_{F}$ and $n$ can be calculated from the intercept and slope, respectively. The linear form of the Langmuir isotherm model [41] can be represented by

$$
\frac{1}{q_{e}}=\frac{1}{q_{\max }}+\left(\frac{1}{b q_{\max }}\right) \frac{1}{C_{e}} .
$$

A plot of $1 / q_{e}$ versus $1 / C_{e}$ was found to be a straight line with $1 / q_{\max }$ as intercept and $1 / b q_{\max }$ as slope, and hence $q_{\max }$ and $b$ can be calculated. Figures 6(a) and 6(b) show Freundlich adsorption isotherm and the Langmuir adsorption isotherm, respectively. The Freundlich constants $n$ and $K_{F}$, Langmuir constants $b$ and $q_{\max }$, and the correlation coefficient $R^{2}$ are given in Table 2 . The calculated value of Freundlich constant $n$ is within the range $(0.1<n<1)$, reported in the literature [42] showing that adsorption is favorable. However, the linearized equation did not give a good correlation for the removal of $\mathrm{Pb}$ (II) ions onto activated carbon, indicating that $\mathrm{Pb}(\mathrm{II})$ adsorption by activated carbon fits better to the Langmuir model than to the Freundlich model.

In addition, a dimensionless constant called separation factor, $R_{L}$, can be used to express an essential feature of Langmuir isotherm [43]:

$$
R_{L}=\frac{1}{1+a C_{m}},
$$

where $C_{m}$ is the initial concentration $(10 \mathrm{mg} / \mathrm{L}$, in this case) of $\mathrm{Pb}$ (II). The value of $R_{L}$ indicates the type of the isotherm to be either unfavorable when $R_{L}>1$, linear if $R_{L}=1$, and favorable if $0<R_{L}<1$ or $R_{L}=0$. The calculated $R_{L}$ was 0.62 indicating that the adsorption of the $\mathrm{Pb}(\mathrm{II})$ was a favorable process. The comparison of maximum monolayer adsorption capacity of $\mathrm{Pb}(\mathrm{II})$ ions onto various activated carbons derived from different precursors is given in Table 3. It should be noted that adsorption capacity varies and depends on the characteristics of an individual adsorbent, the extent of surface modification, the analytical method used for decontamination (batch method, column, reactors, etc.), heat treatment temperatures, and the initial concentration of 


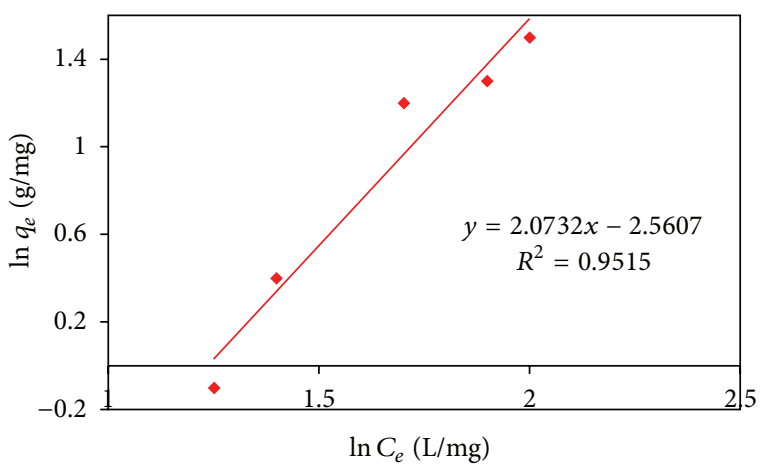

(a)

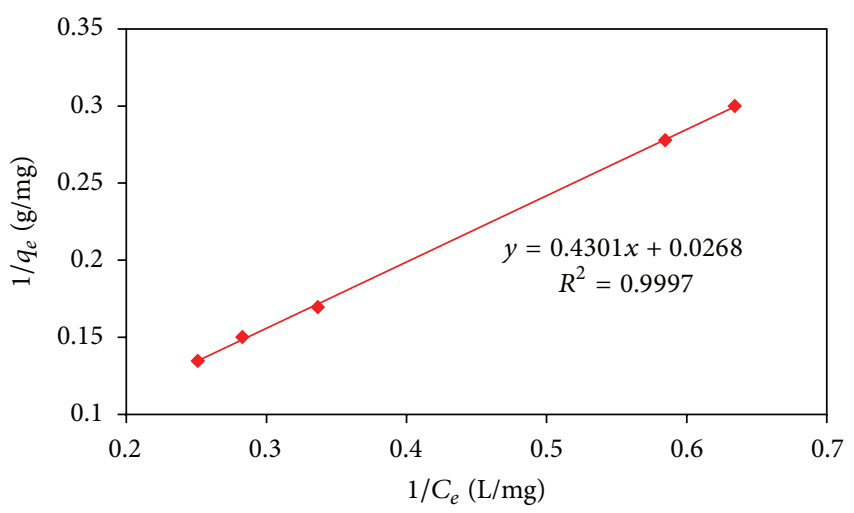

(b)

FIGURE 6: (a) Freundlich isotherm for $\mathrm{Pb}(\mathrm{II})$ ion adsorption using activated carbon (b) Langmuir isotherm for $\mathrm{Pb}$ (II) adsorption using activated carbon $(10 \mathrm{mg} / \mathrm{L}, \mathrm{pH}=5.4$, and dosage $=1.2 \mathrm{~g})$.

TABLE 3: Performance of activated carbons from various precursors for adsorption of $\mathrm{Pb}$ (II) from aqueous solutions.

\begin{tabular}{|c|c|c|c|c|}
\hline Precursor & Activation & Conditions: $\mathrm{pH}$; agitation time & Maximum adsorbent $(\mathrm{mg} / \mathrm{g})$ & Reference \\
\hline Hazelnut husks & Chemical activation by $\mathrm{ZnCl}_{2}$ & $6.7 ; 60 \mathrm{~min}$ & 13.05 & [18] \\
\hline Coffee residue & Chemical activation by $\mathrm{ZnCl}_{2}$ & $5.8 ; 2 \mathrm{~h}$ & 63 & {$[23]$} \\
\hline Rice husk & Chemical activation by $\mathrm{H}_{3} \mathrm{PO}_{4}$ & - & 138.89 & [27] \\
\hline Coconut shell & Chemical activation by $\mathrm{H}_{2} \mathrm{SO}_{4}$ & $4.5 ; 2 \mathrm{~h}$ & 26.50 & {$[35]$} \\
\hline Tamarind wood & Chemical activation by $\mathrm{ZnCl}_{2}$ & $6.5 ; 50 \mathrm{~min}$ & 43.85 & {$[45]$} \\
\hline Tamarind wood & Chemical activation by $\mathrm{H}_{2} \mathrm{SO}_{4}$ & $6.5 ; 40 \mathrm{~min}$ & 134.22 & {$[45]$} \\
\hline Cashew nut shell & Chemical activation by $\mathrm{H}_{2} \mathrm{SO}_{4}$ & $5.0 ; 30 \mathrm{~min}$ & 408.6 & {$[46]$} \\
\hline Sugarcane bagasse & Chemical activation by $\mathrm{H}_{2} \mathrm{SO}_{4}$ & 5 ; not given & 7.297 & {$[47]$} \\
\hline Maize tassel & Chemical activation by $\mathrm{H}_{2} \mathrm{SO}_{4}$ & $5.4 ; 60 \mathrm{~min}$ & 37.31 & This study \\
\hline
\end{tabular}

TABLE 4: Desorption of $\mathrm{Pb}(\mathrm{II})$ ions from activated carbon using $\mathrm{HCl}$.

\begin{tabular}{lccccc}
\hline $\begin{array}{l}\text { Initial } \mathrm{Pb}(\mathrm{II}) \\
\text { concentration }(\mathrm{mg} / \mathrm{L})\end{array}$ & $\begin{array}{c}\text { \% } \mathrm{Pb}(\mathrm{II}) \text { ion } \\
\text { removal }\end{array}$ & \multicolumn{4}{c}{ \% Recovery of $\mathrm{Pb}(\mathrm{II})$ ions } \\
\hline 10 & 91.8 & 74.25 & 80.50 & 90.60 & 87.65 \\
20 & 86.7 & 70.21 & 77.54 & 83.29 & 80.50 \\
30 & 83.9 & 66.25 & 74.58 & 79.32 & 75.65 \\
50 & 81.3 & 58.2 & 65.65 & 70.52 & 68.56 \\
\hline
\end{tabular}

the adsorbate used [26, 44]. As can be seen from Table 3, activated carbon from maize tassel precursor in this work has reasonable adsorption capacity $(37.31 \mathrm{mg} / \mathrm{g}$ ) for $\mathrm{Pb}(\mathrm{II})$ ions, closer or higher than some agro-based derived activated carbons but lower than other highly lignocellulosic plants such as Tamarind wood (134.22 mg/g) and cashew nut shell $(138.89 \mathrm{mg} / \mathrm{g})$ just to mention a few.

3.6. Desorption Studies. For wastewater treatment, regeneration of the adsorbent material is of importance in economic development, since it helps to protect the environment and recycling of the adsorbate ( $\mathrm{Pb}$ (II) ions) and adsorbent (activated carbon). The successful application of this technique also reduces the dependence on thermal activation, incineration, and land disposal, which directly or indirectly increases environmental pollution [1]. Desorption studies help in process design systems by giving information on the mechanism and recovery of adsorbates from industrial wastewater and the adsorbent. In this study, desorption results are presented in Table 4. It can be observed that desorption rate increases with increase in $\mathrm{HCl}$ concentration but attained a constant at $0.2 \mathrm{M} \mathrm{HCl}$.

\section{Conclusions}

Maize tassel, a residue released in a substantial amount in the agricultural sector, was converted into activated carbon. The material under consideration is not only economical but is a waste product. Hence, its use as an adsorbent would on one hand solve the problem of its disposal and on other hand provide an effective adsorbent for the treatment of metal bearing wastewaters. Results from adsorption studies revealed that the percentage removal decreased with increase in the initial concentration of $\mathrm{Pb}$ (II) ions suggesting the applicability of the activated carbon at lower concentrations. Adsorption equilibrium for the metal was reached in about $60 \mathrm{~min}$. It was also observed that the adsorption was $\mathrm{pH}$ dependent and the maximum $\mathrm{Pb}$ removal of $96.6 \%$ occurred at $\mathrm{pH}$ of 5.4. An increase in the activated carbon dosage leads to an increase in $\mathrm{Pb}$ (II) ions removal due to a corresponding increase in the number of active sites. 


\section{Acknowledgment}

The authors are grateful for the Department of Chemical Technology, Midlands State University, Gweru, Zimbabwe, for providing facilities.

\section{References}

[1] P. S. Kumar, "Adsorption of lead(II) ions from simulated wastewater using natural waste: a kinetic, thermodynamic and equilibrium study," Environmental Progress and Sustainable Energy, 2013.

[2] A. B. Dekhil, Y. Hannachi, A. Ghorbel, and T. Boubaker, "Removal of lead and cadmium ions from aqueous solutions using the macroalga Caulerpa racemosa," Chemistry and Ecology, vol. 27, no. 3, pp. 221-234, 2011.

[3] T. A. Saleh and V. K. Gupta, "Column with CNT/magnesium oxide composite for lead(II) removal from water," Environmental Science and Pollution Research, vol. 19, no. 4, pp. 1224-1228, 2012.

[4] N. M. Mubarak, S. Daniel, M. Khalid, and J. Tan, "Comparative study of functionalize and non-functionalized carbon nanotube for removal of copper from polluted water," International Journal of Chemical and Environmental Engineering, vol. 3, pp. 1-4, 2012.

[5] World Health Organization, Guidelines for Drinking Water Quality, vol. 1-2, World Health Organization, Geneva, Switzerland, 1984.

[6] A. B. P. Marín, J. F. Ortuño, M. I. Aguilar, V. F. Meseguer, J. Sáez, and M. Lloréns, "Use of chemical modification to determine the binding of $\mathrm{Cd}(\mathrm{II}), \mathrm{Zn}$ (II) and $\mathrm{Cr}$ (III) ions by orange waste," Biochemical Engineering Journal, vol. 53, no. 1, pp. 2-6, 2010.

[7] V. K. Gupta, I. Ali, T. A. Saleh, A. Nayak, and S. Agarwal, "Chemical treatment technologies for waste-water recyclingan overview," The Royal Society of Chemistry, vol. 2, no. 16, pp. 6380-6388, 2012.

[8] J. M. Lezcano, F. González, A. Ballester, M. L. Blázquez, J. A. Muñoz, and C. García-Balboa, "Sorption and desorption of $\mathrm{Cd}, \mathrm{Cu}$ and $\mathrm{Pb}$ using biomass from an eutrophized habitat in monometallic and bimetallic systems," Journal of Environmental Management, vol. 92, no. 10, pp. 2666-2674, 2011.

[9] K. Mohanty, D. Das, and M. N. Biswas, "Adsorption of phenol from aqueous solutions using activated carbons prepared from Tectona grandis sawdust by $\mathrm{ZnCl}_{2}$ activation," Chemical Engineering Journal, vol. 115, no. 1-2, pp. 121-131, 2005.

[10] K. Mohanty, D. Das, and M. N. Biswas, "Preparation and characterization of activated carbons from Sterculia alata nutshell by chemical activation with zinc chloride to remove phenol from wastewater," Adsorption, vol. 12, no. 2, pp. 119-132, 2006.

[11] J. P. Chen and L. Yang, "Chemical modification of Sargassum sp. for prevention of organic leaching and enhancement of uptake during metal biosorption," Industrial and Engineering Chemistry Research, vol. 44, no. 26, pp. 9931-9942, 2005.

[12] I. W. Mwangi, J. C. Ngila, and J. O. Okonkwo, "A comparative study of modified and unmodified maize tassels for removal of selected trace metals in contaminated water," Toxicological and Environmental Chemistry, vol. 94, no. 1, pp. 20-39, 2012.

[13] I. W. Mwangi and J. C. Ngila, "Removal of heavy metals from contaminated water using ethylenediamine-modified green seaweed (Caulerpa serrulata)," Physics and Chemistry of the Earth, vol. 50-52, pp. 111-120, 2012.
[14] M. M. Rao, A. Ramesh, G. P. C. Rao, and K. Seshaiah, "Removal of copper and cadmium from the aqueous solutions by activated carbon derived from Ceiba pentandra hulls," Journal of Hazardous Materials, vol. 129, no. 1-3, pp. 123-129, 2006.

[15] V. K. Gupta, A. Mittal, A. Malviya, and J. Mittal, "Adsorption of carmoisine A from wastewater using waste materials-bottom ash and deoiled soya," Journal of Colloid and Interface Science, vol. 335, no. 1, pp. 24-33, 2009.

[16] S. Ong, S. Yip, P. Keng, S. Lee, and Y. H. Papaya, "(Carica papaya) seed as a low-cost sorbent for zinc removal," African Journal of Agricultural Research, vol. 7, no. 5, pp. 810-819, 2012.

[17] Ö. Gerçel and H. F. Gerçel, "Adsorption of lead(II) ions from aqueous solutions by activated carbon prepared from biomass plant material of Euphorbia rigida," Chemical Engineering Journal, vol. 132, no. 1-3, pp. 289-297, 2007.

[18] M. Imamoglu and O. Tekir, "Removal of copper (II) and lead (II) ions from aqueous solutions by adsorption on activated carbon from a new precursor hazelnut husks," Desalination, vol. 228, no. 1-3, pp. 108-113, 2008.

[19] A. Özer, "Removal of $\mathrm{Pb}(\mathrm{II})$ ions from aqueous solutions by sulphuric acid-treated wheat bran," Journal of Hazardous Materials, vol. 141, no. 3, pp. 753-761, 2007.

[20] R. H. Hasas, A. Arami-Neya, W. M. A. W. Daud, and J. N. Sahu, "Preparation and characterization of activated carbon from apple waste by microwave assisted phosphoric acid activation: application in methylene blue adsorption," BioResources, vol. 8, no. 2, pp. 2950-2966, 2013.

[21] O. S. Amuda, A. A. Giwa, and I. A. Bello, "Removal of heavy metal from industrial wastewater using modified activated coconut shell carbon," Biochemical Engineering Journal, vol. 36, no. 2, pp. 174-181, 2007.

[22] K. Mohanty, M. Jha, B. C. Meikap, and M. N. Biswas, "Removal of chromium (VI) from dilute aqueous solutions by activated carbon developed from Terminalia arjuna nuts activated with zinc chloride," Chemical Engineering Science, vol. 60, no. 11, pp. 3049-3059, 2005.

[23] F. Boudrahem, F. Aissani-Benissad, and H. Aït-Amar, "Batch sorption dynamics and equilibrium for the removal of lead ions from aqueous phase using activated carbon developed from coffee residue activated with zinc chloride," Journal of Environmental Management, vol. 90, no. 10, pp.3031-3039, 2009.

[24] A. El Nemr, A. El Sikaily, A. Khaled, and O. Abdelwahab, "Removal of toxic chromium(VI) from aqueous solution by activated carbon using Casuarina equisetifolia," Chemistry and Ecology, vol. 23, no. 2, pp. 119-129, 2007.

[25] A. Esmaeili, S. Ghasemi, and J. Sohrabipour, "Biosorption of copper from wastewater by activated carbon preparation from alga Sargassum sp.," Natural Product Research, vol. 24, no. 4, pp. 341-348, 2010.

[26] K. Nath, S. Panchani, M. S. Bhakhar, and S. Chatrola, "Preparation of activated carbon from dried pods of Prosopis cineraria with zinc chloride activation for the removal of phenol," Environmental Science and Pollution Research, vol. 20, no. 6, pp. 4030-4045, 2013.

[27] A. O. Dada, J. O. Ojediran, and A. P. Olalekan, "Sorption of $\mathrm{Pb}^{2+}$ from aqueous solution unto modified rice husk: isotherms studies," Advances in Physical Chemistry, vol. 2013, Article ID 842425, 6 pages, 2013.

[28] M. Sathishkumar, A. R. Binupriya, D. Kavitha, and S. E. Yun, "Kinetic and isothermal studies on liquid-phase adsorption of 2,4-dichlorophenol by palm pith carbon," Bioresource Technology, vol. 98, no. 4, pp. 866-873, 2007. 
[29] K. Periasamy and C. Namasivayam, "Removal of copper(II) by adsorption onto peanut hull carbon from water and copper plating industry wastewater," Chemosphere, vol. 32, no. 4, pp. 769-789, 1996.

[30] W. Li, L. Zhang, J. Peng, N. Li, S. Zhang, and S. Guo, “Tobacco stems as a low cost adsorbent for the removal of $\mathrm{Pb}$ (II) from wastewater: equilibrium and kinetic studies," Industrial Crops and Products, vol. 28, no. 3, pp. 294-302, 2008.

[31] Z. Reddad, C. Gerente, Y. Andres, and P. Le Cloirec, "Adsorption of several metal ions onto a low-cost biosorbent: kinetic and equilibrium studies," Environmental Science and Technology, vol. 36, no. 9, pp. 2067-2073, 2002.

[32] S. Doyurum and A. Çelik, "Pb(II) and $\mathrm{Cd}(\mathrm{II})$ removal from aqueous solutions by olive cake," Journal of Hazardous Materials, vol. 138, no. 1, pp. 22-28, 2006.

[33] S. Tunali, T. Akar, A. S. Özcan, I. Kiran, and A. Özcan, "Equilibrium and kinetics of biosorption of lead(II) from aqueous solutions by Cephalosporium aphidicola," Separation and Purification Technology, vol. 47, no. 3, pp. 105-112, 2006.

[34] J. R. Srinivasa, R. C. Kesava, and G. Prabhakar, "Optimization of biosorption performance of Casuarina leaf powder for the removal of lead using central composite design," Journal of Environmental and Analytical Toxicology, vol. 3, article 166, 2013.

[35] M. Sekar, V. Sakthi, and S. Rengaraj, "Kinetics and equilibrium adsorption study of lead(II) onto activated carbon prepared from coconut shell," Journal of Colloid and Interface Science, vol. 279, no. 2, pp. 307-313, 2004.

[36] R. Ayyappan, A. C. Sophia, K. Swaminathan, and S. Sandhya, "Removal of $\mathrm{Pb}$ (II) from aqueous solution using carbon derived from agricultural wastes," Process Biochemistry, vol. 40, no. 3-4, pp. 1293-1299, 2005.

[37] M. Nadeem, A. Mahmood, S. A. Shahid, S. S. Shah, A. M. Khalid, and G. McKay, "Sorption of lead from aqueous solution by chemically modified carbon adsorbents," Journal of Hazardous Materials, vol. 138, no. 3, pp. 604-613, 2006.

[38] C. M. Zvinowanda, J. O. Okonkwo, M. M. Sekhula, N. M. Agyei, and R. Sadiku, "Application of maize tassel for the removal of $\mathrm{Pb}, \mathrm{Se}, \mathrm{Sr}, \mathrm{U}$ and $\mathrm{V}$ from borehole water contaminated with mine wastewater in the presence of alkaline metals," Journal of Hazardous Materials, vol. 164, no. 2-3, pp. 884-891, 2009.

[39] O. F. Olorundare, R. W. M. Krause, J. O. Okonkwo, and B. B. Mamba, "Potential application of activated carbon from maize tassel for the removal of heavy metals in water," Physics and Chemistry of the Earth, vol. 50-52, pp. 104-110, 2012.

[40] H. M. F. Freundlich, "Over the adsorption in solution," The Journal of Physical Chemistry, vol. 57, pp. 384-470, 1906.

[41] I. Langmuir, "The constitution and fundamental properties of solids and liquids-part I: solids," Journal of the American Chemical Society, vol. 38, no. 2, pp. 2221-2295, 1916.

[42] C. Raji and T. S. Anirudhan, "Batch Cr(VI) removal by polyacrylamide-grafted sawdust: kinetics and thermodynamics," Water Research, vol. 32, no. 12, pp. 3772-3780, 1998.

[43] K. R. Hall, L. C. Eagleton, A. Acrivos, and T. Vermeulen, "Pore- and solid-diffusion kinetics in fixed-bed adsorption under constant-pattern conditions," Industrial and Engineering Chemistry Fundamentals, vol. 5, no. 2, pp. 212-223, 1966.

[44] W. C. Lim, C. Srinivasakannan, and N. Balasubramanian, "Activation of palm shells by phosphoric acid impregnation for high yielding activated carbon," Journal of Analytical and Applied Pyrolysis, vol. 88, no. 2, pp. 181-186, 2010.
[45] J. Acharya, J. N. Sahu, C. R. Mohanty, and B. C. Meikap, "Removal of lead(II) from wastewater by activated carbon developed from Tamarind wood by zinc chloride activation," Chemical Engineering Journal, vol. 149, no. 1-3, pp. 249-262, 2009.

[46] P. S. Kumar, S. Ramalingam, R. V. Abhinaya, K. V. Thiruvengadaravi, P. Baskaralingam, and S. Sivanesan, "Lead(II) adsorption onto sulphuric acid treated cashew nut shell," Separation Science and Technology, vol. 46, no. 15, pp. 2436-2449, 2011.

[47] M. Á. Martín-Lara, I. L. R. Rico, I. D. L. C. A. Vicente, G. B. García, and M. C. de Hoces, "Modification of the sorptive characteristics of sugarcane bagasse for removing lead from aqueous solutions," Desalination, vol. 256, no. 1-3, pp. 58-63, 2010 . 

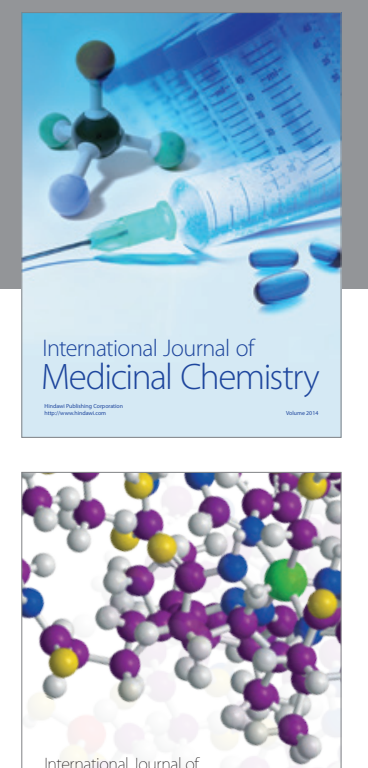

\section{Carbohydrate} Chemistry

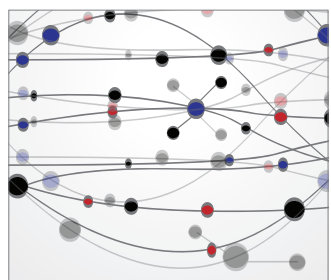

The Scientific World Journal
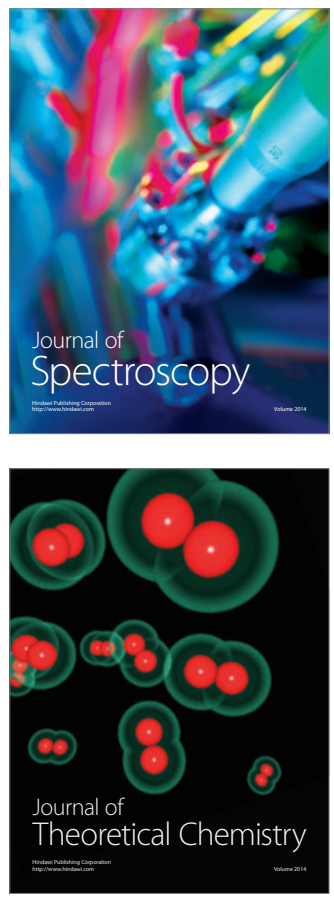
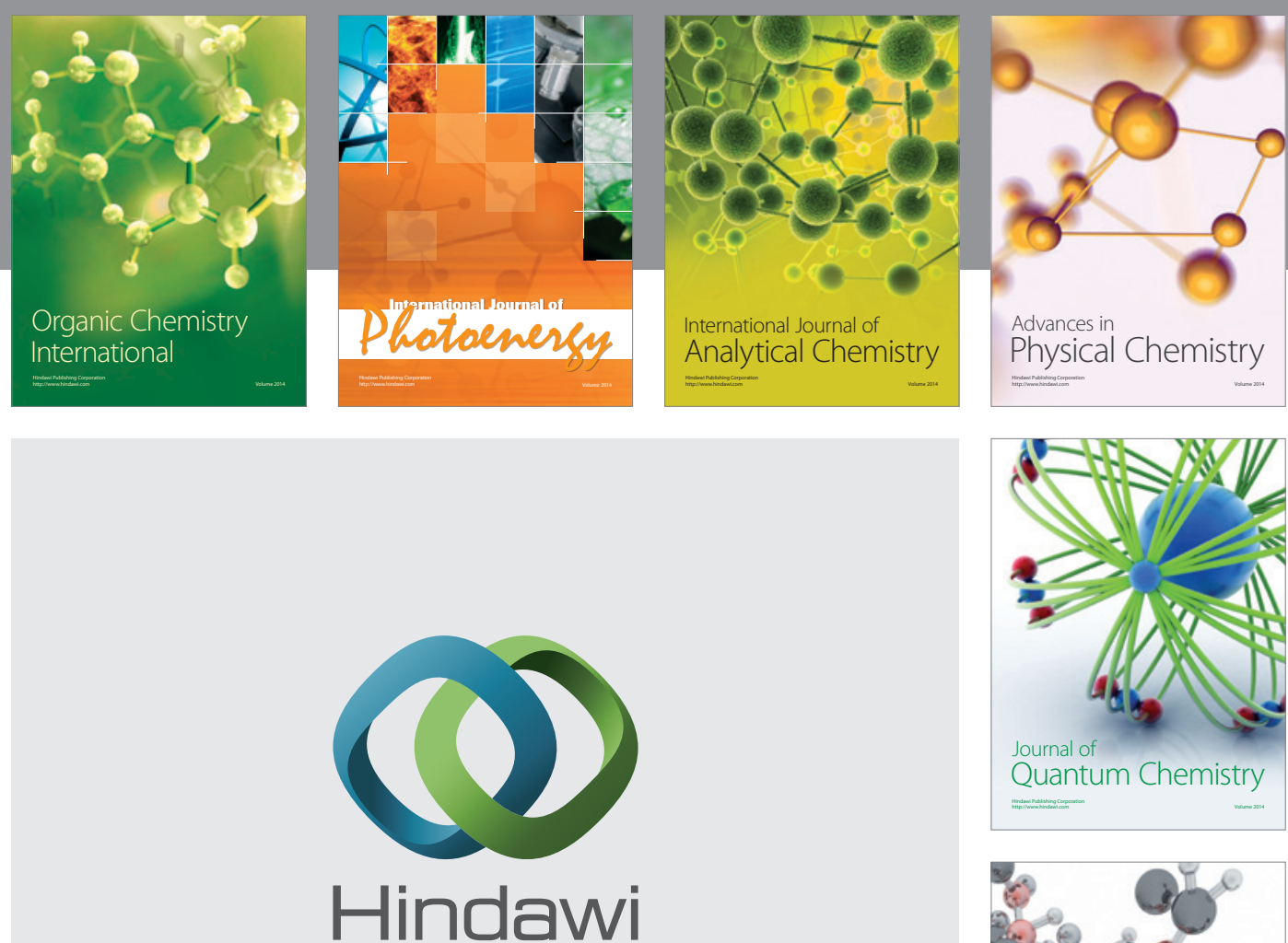

Submit your manuscripts at

http://www.hindawi.com

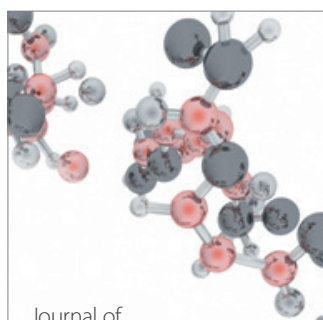

Analytical Methods

in Chemistry

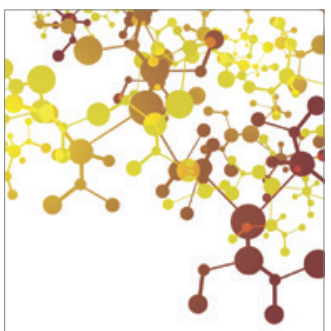

Journal of

Applied Chemistry

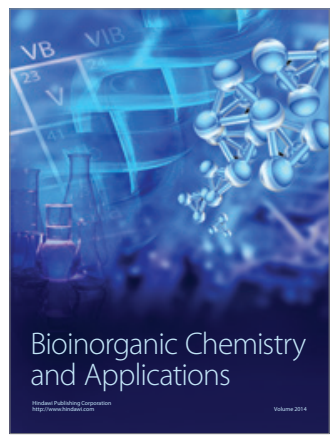

Inorganic Chemistry
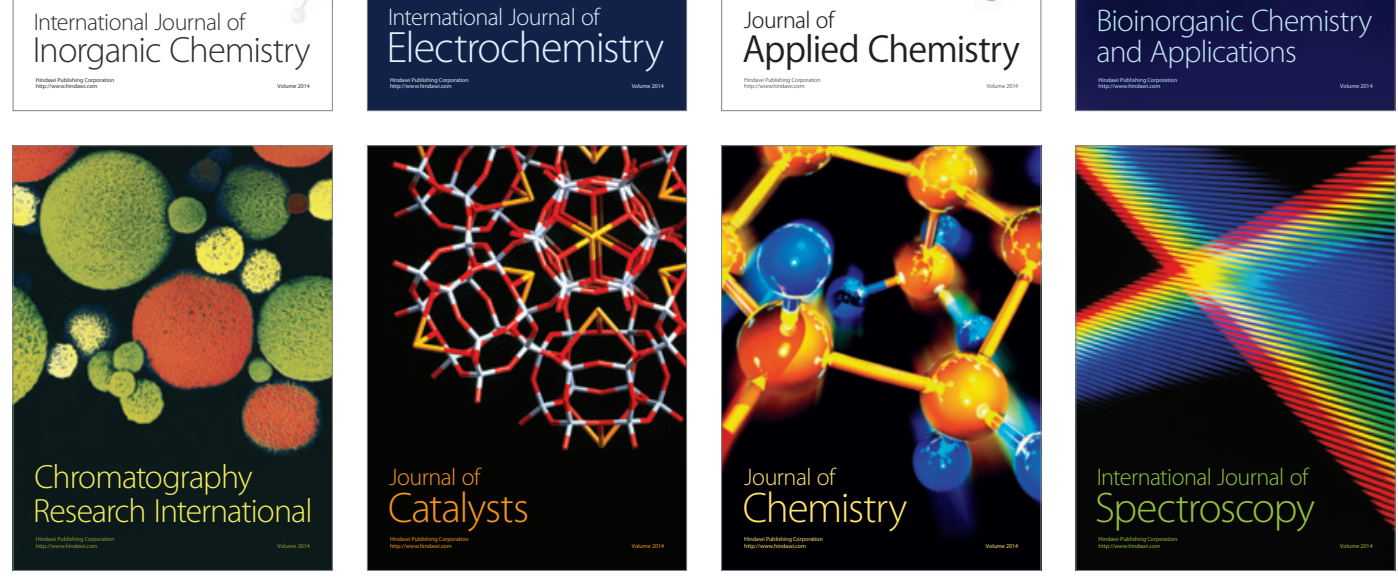